\title{
In vitro macrophage cytotoxicity of five calcium silicates
}

\author{
V SKAUG, ${ }^{1}$ R DAVIES, ${ }^{2}$ AND B GYLSETH \\ From the Institute of Occupational Health, ' PO Box 8149 Dep, Oslo 1, Norway, and the MRC \\ Pneumoconiosis Unit, ${ }^{2}$ Llandough Hospital, Penarth, S Glamorgan, UK
}

ABSTRACT Five calcium silicate minerals (two naturally occurring and three synthetic compounds) with defined morphology and chemical composition were compared for their cytotoxic and lysosomal enzyme releasing effects on unstimulated mouse peritoneal macrophages in vitro. One synthetic material, a fibrous tobermorite, was cytotoxic towards the cells, and two naturally occurring wollastonites induced selective release of $\beta$-glucuronidase from the cells.

Calcium silicates $(\mathrm{CaSi})$ are used in a variety of industrial products including ceramics, paints, abrasives, adhesives, and as reinforcing fillers in plastics and rubber; they have recently become important as substitutes for asbestos in insulation materials. The naturally occurring $\mathrm{CaSi}$, wollastonite $\left(\mathrm{CaSiO}_{3}\right)$, occurs predominantly as contact metamorphic deposits formed between limestones and igneous rocks. The commercial product may be associated with minerals such as garnet, diopside, epidote, calcite, and quartz. The cleavage of mined mineral masses results in acicular or fibrous varieties, the structure of which imparts high strength to the mineral which is important for many of its uses. Pure wollastonite contains $48.3 \% \mathrm{CaO}$ and $51.7 \% \mathrm{SiO}_{2}{ }^{1}$ Reserves of naturally occurring wollastonite are continuously being exploited, mainly in the United States and Finland but also in Mexico, Kenya, India, USSR, New Zealand, Sudan, and South Africa.

Many countries have started production of synthetic $\mathrm{CaSi}$ compounds, which are produced by hydrothermal reaction between quartz and calcite. Among these hydrated varieties, tobermorite and xonotlite are the most common crystalline structures that may be formed. The mineral morphology depends on physical factors such as the pressure and temperature during processing, and as the chemical reaction is not always complete, quartz and calcite may be present as impurities in the final product.

There are few reports on the hazards to human health after exposure to CaSi. Shasby et al found no evidence of obstructive or restrictive lung disease in 104 wollastonite mine and mill workers with a mean

Received 16 December 1982

Accepted 24 January 1983 exposure time of $9 \cdot 2$ years. ${ }^{2}$ In a study of 46 Finnish quarry workers exposed to wollastonite for more than 10 years (mean 21.5 years), however, Huuskonen et al reported an increase in lung fibrosis and bilateral pleural thickening. ${ }^{3}$ Lung function studies also indicated the possibility of peripheral airways disease.

The intratracheal instillation of synthetic $\mathrm{CaSi}$ into rat lungs ${ }^{4}$ produced some biochemical changes in the cells and medium of lung lavage material, although after four weeks many of the alterations had almost completely reversed. In in vitro studies $\mathrm{CaSi}$ were active in reducing the viability of alveolar macrophages and, like chrysotile, one $\mathrm{CaSi}$ interfered with the deposition of collagen in lung fibroblast cultures. The $\mathrm{CaSi}$ were more reactive than titanium dioxide.

The haemolytic activity of $\mathrm{CaSi}$ has been found to be related to the surface area of the minerals and their crystalline structure but not to mineral morphology. ${ }^{6}$ On standing in solution for a few days the $\mathrm{CaSi}$ released calcium, their haemolytic activity decreased, but the significance of the calcium release for haemolysis remains to be established.

In this paper we report on the effects of five $\mathrm{CaSi}$ (used in the haemolysis study ${ }^{6}$ ) towards mouse peritoneal macrophages in vitro. Dusts cytotoxic towards macrophages in vitro usually cause fibrosis in animal studies, ${ }^{7-9}$ thus the potential fibrogenicity of the $\mathrm{CaSi}$ can be evaluated.

There are reports that some materials which cause chronic inflammation leading to lung fibrosis can cause the selective release of lysosomal enzymes from macrophages without concomitant cell death. ${ }^{10}$ The only mineral dust that has been claimed to show 
this phenomenon is chrysotile asbestos." In other studies, however, chrysotile while releasing large amounts of lysosomal enzymes is invariably cytotoxic towards macrophages. ${ }^{12}$ Thus the release of a lysosomal enzyme from macrophages was also followed.

\section{Materials and methods}

SOURCE, PREPARATION, AND

CHARACTERISATION OF CaSi DUST SAMPLES

The following CaSi were used in the study:

CaSi (A) Natural US wollastonite (obtained from MRC Pneumoconiosis Unit, code PU 29R);

CaSi (B) Natural Finnish wollastonite (donated by Partek OY, Finland);

CaSi (C) Synthetic $\beta$-wollastonite (donated by Ytong AB, Sweden);

CaSi (D) Synthetic tobermorite (donated by Ytong AB, Sweden);

$\mathrm{CaSi}$ (E) Synthetic tobermorite (donated as pipe line insulation material from an oil exploration installation in the North Sea).

A dust cloud was created in a closed chamber by a Timbrell dust feeder ${ }^{13}$ for the fibrous samples and a Wright dust feeder ${ }^{14}$ for the non-fibrous samples. Respirable samples were collected from the chamber with a Hexhlet dust sampler at $50 \mathrm{l} / \mathrm{min}$ : 50-100 $\mu \mathrm{g}$ and $1 \mathrm{mg}$ samples of each type respectively were suspended in $50 \mathrm{ml}$ distilled water with a few per cent ethanol and treated in an ultrasonic bath for five minutes. The 50-100 $\mu \mathrm{g}$ samples were filtered on $47 \mathrm{~mm}$ diameter $0.2 \mu \mathrm{m}$ pore size Nuclepore polycarbonate membranes and the $1 \mathrm{mg}$ samples were filtered on $25 \mathrm{~mm}$ diameter $0.8 \mu \mathrm{m}$ pore size membranes of the same type. Small pieces of the $47 \mathrm{~mm}$ membranes were cut and mounted on a carbon stub, coated with gold, and introduced into a Jeol Jsm-35 scanning electron microscope (SEM). The $25 \mathrm{~mm}$ membranes were introduced into a Philips $x$ ray diffractometer (XRD) equipped with a $\mathrm{CuK} \alpha$ anode, a rotating sample holder, and a graphite crystal monochromator. The samples were scanned from $15-55^{\circ} 2 \theta$, and the peaks were identified using the JCPDS search manual ${ }^{15}$ and selected powder diffraction data. ${ }^{16}$ The quartz content was determined as described by Bye et al. ${ }^{17}$ Additional $1 \mathrm{mg}$ samples were analysed by infrared spectrometry (IR) for quartz using the $\mathrm{KBr}$-pellet technique. $^{18}$

\section{CULTURE OF MACROPHAGES WITH DUSTS}

Unstimulated mouse peritoneal macrophages were obtained by lavage of $22-27 \mathrm{~g}$ female TO mice (Tuck and Son Ltd, Battlesbridge, Essex) with $3 \mathrm{ml}$ Medium 199 (Flow Laboratories, Irvine, Scotland) containing $5 \mathrm{IU}$ heparin, $100 \mathrm{U}$ benzylpenicillin, and $100 \mu \mathrm{g}$ streptomycin/ml. Approximately $1 \cdot 2 \times$ $10^{6}$ cells (in $2 \mathrm{ml}$ of the above medium) were added to each well of Linbro tissue culture multiwell plates (Flow Laboratories, Irvine, Scotland-well diameter of $24 \mathrm{~mm}$ ) and left for one hour at $37^{\circ} \mathrm{C}$ in a $5 \% \mathrm{CO}_{2} / 95 \%$ air atmosphere.

At the end of the period, the non-adherent cells were removed by washing with phosphate buffered saline (PBS) and $2 \mathrm{ml}$ Medium 199 containing the antibiotics referred to above and $10 \%$ new born calf serum (Flow Laboratories, Irvine, Scotland) was added. This serum had previously been heatinactivated $\left(56^{\circ}\right.$ for 30 minutes) and acid treated..$^{19}$ Cultures were left for 24 hours at $37^{\circ} \mathrm{C}$ in a $5 \%$ $\mathrm{CO}_{2} / 95 \%$ air atmosphere before addition of fresh medium containing dusts.

Stock dust solutions were made up in PBS at approximate concentrations, ultrasonication being used to disperse the dust. The dust was added to the above medium containing $10 \%$ serum at various concentrations (see results) and left for two to three hours at $37^{\circ} \mathrm{C}$ before addition to the macrophage cultures. Two millilitres of "dusted" medium were added to each of three culture dishes which were then incubated for another 18 hours.

At the end of this period the medium was collected and the adherent cells disrupted by the addition of $2 \mathrm{ml}$ saline containing $0.1 \%$ Triton X100 and $0.1 \%$ bovine serum albumin, and by rubbing the dish with a sterile siliconised rubber bung. Both medium and cell lysates were centrifuged at $500 \mathrm{~g}$ for 10 minutes and the supernatants assayed for lactate dehydrogenase (LDH) and $\beta$-glucuronidase $(\beta \mathrm{Glu})$ by a continuous flow fluorimetric method ${ }^{20}$ using a Perkin Elmer model 3000 fluorescence spectrometer.

The release of $\mathrm{LDH}$ from the cells into the culture medium is an indicator of dust cytotoxicity and is calculated as:

$$
\begin{array}{r}
\% \text { enzyme released into } \\
\text { culture medium }
\end{array}=\frac{M}{M+C} \times 100
$$

where $\mathbf{M}=$ enzyme activity of medium and $\mathrm{C}=$ enzyme activity of cell lysate.

The effects of CaSi were compared with DQ12 quartz standard ${ }^{21}$ and magnetite, a non-fibrogenic dust. $^{22}$

\section{Results}

CHARACTERISATION OF THE CALCIUM SILICATES

Figure 1 shows SEM micrographs of the calcium silicates (CaSi). CaSi (A) the natural US wollasto- 

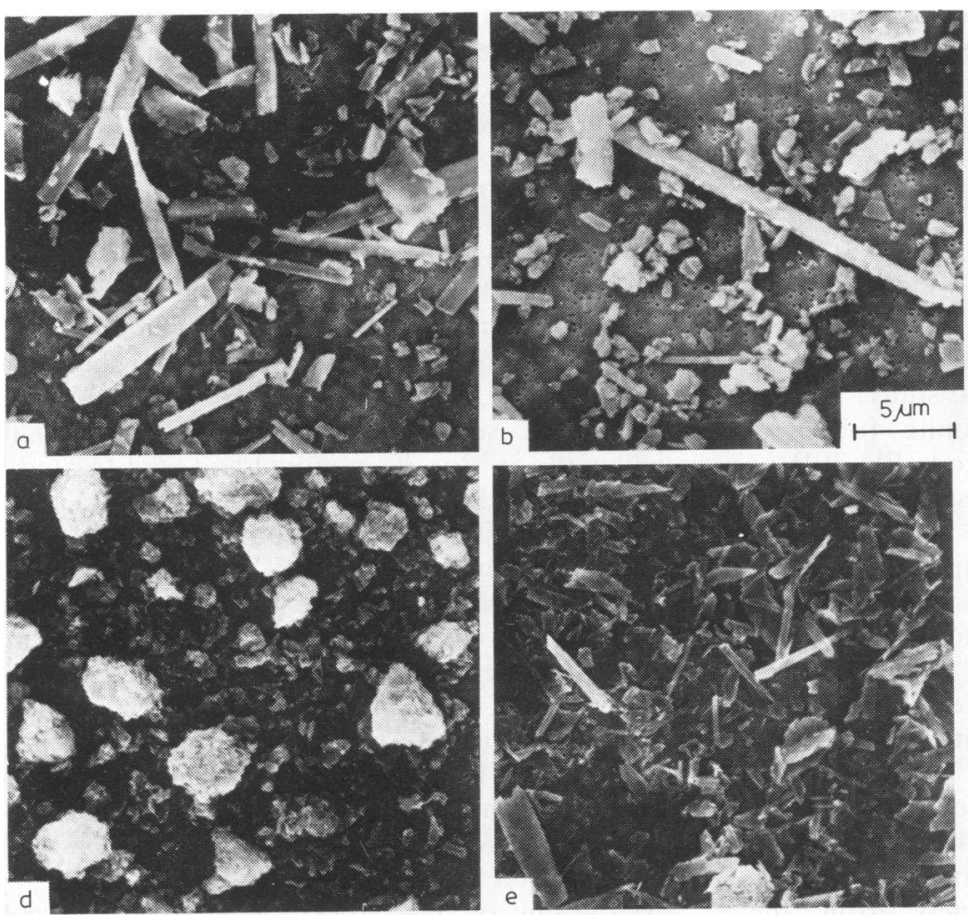

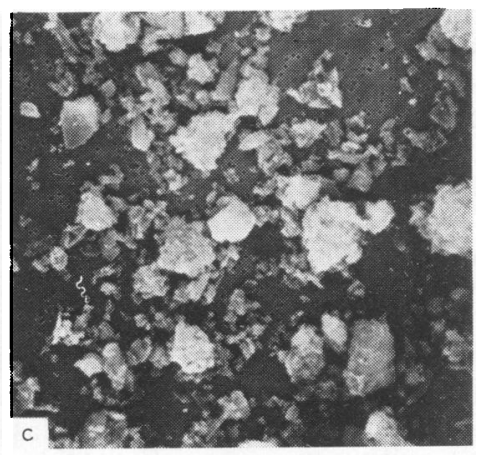

Fig 1 Scanning electron micrographs of calcium silicates: (a) natural US wollastonite (CaSi $(A))$; (b) natural Finnish wollastonite ( $\mathrm{CaSi}(\mathrm{B}))$; (c) synthetic wollastonite (CaSi (C)); (d) synthetic tobermorite (CaSi (D)); and (e) synthetic tobermorite (CaSi $(E))$.
Table 1 Size distribution of $\mathrm{CaSi}(A) \%$ fibres in each size category

\begin{tabular}{lllll}
\hline $\begin{array}{c}\text { Diameter } \\
\text { range }(\mu \mathrm{m})\end{array}$ & $0-1$ & $1-2$ & $2-3$ & $3-4$ \\
$\begin{array}{c}\text { Length } \\
\text { range }(\mu \mathrm{m})\end{array}$ & & & & \\
\hline $2-4$ & 16 & 2 & & \\
$4-10$ & 25 & 7 & 1 & \\
$10-30$ & 11 & 8 & 8 & 3 \\
$30-100$ & 3 & 7 & 6 & 2 \\
$100-200$ & & & 1 & 1 \\
\hline
\end{tabular}

nite is made up of both fibrous* and non-fibrous particles. Table 1 shows the size distribution of the fibrous particles; over half the fibres are less than 1

${ }^{*}$ Defined as particles having a length/diameter ratio greater than 3 . $\mu \mathrm{m}$ in diameter and $50 \%$ longer than $10 \mu \mathrm{m}$. By contrast, $\mathrm{CaSi}$ (B), a natural Finnish wollastonite, contains, for the most part, non-fibrous particles. The size distribution of those fibres present is shown in table $2 ; 91 \%$ are less than $1 \mu \mathrm{m}$ in diameter and only $3 \%$ longer than $7 \mu \mathrm{m}$.

Both the synthetic wollastonite $(\mathrm{CaSi}(\mathrm{C}))$ and tobermorite ( $\mathrm{CaSi}(\mathrm{D}))$ were non-fibrous but the synthetic tobermorite (CaSi (E)) has a fibrous morphology. Table 3 shows the size distributions of the fibres; the fibres are shorter and narrower than those present in CaSi (B).

Table 4 shows the quartz content of the materials; $\mathrm{CaSi}$ (D) and $\mathrm{CaSi}$ (C) contain respectively $9 \%$ and $10 \%$ quartz as determined by $x$ ray diffraction analysis. On infrared analysis, however, less than

Table 2 Size distribution of CaSi (B) \% fibres in each size category

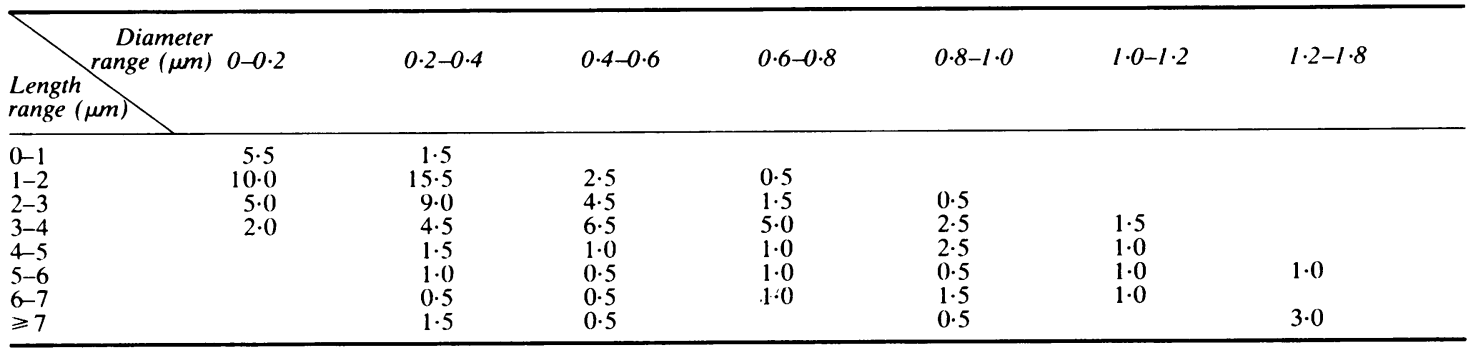


Table 3 Size distribution of CaSi (E) \% fibres in each size category

\begin{tabular}{l}
$\begin{array}{c}\text { Diameter } \\
\text { range } \\
(\mu \mathrm{m})\end{array}$ \\
$\begin{array}{l}\text { Length } \\
\text { range }(\mu \mathrm{m})\end{array}$ \\
\hline $0-1$
\end{tabular}

$3 \%$ was detected. Table 5 gives the specific surface areas of the $\mathrm{CaSi}$ samples as determined by the gas absorption technique. ${ }^{23}$

\section{CYTOTOXICITY AND LYSOSOMAL ENZYME} RELEASE STUDIES

Figure 2 shows the release of the cytoplasmic enzyme lactate dehydrogenase (LDH) (an indication of cytotoxicity) from the dusted macrophage cultures. The fibrogenic dust quartz DQ12 was cytotoxic towards the cells; the non-fibrogenic mineral magnetite released only low levels of LDH from the cells.

The calcium silicates A, B, C, and D had little effect on $\mathrm{LDH}$ release but $\mathrm{CaSi}(\mathrm{E})$, the fibrous tobermorite, was clearly cytotoxic. In a separate assay for cell viability using the Trypan Blue dye exclusion method, CaSi (E) also produced the lowest number of viable cells.

The CaSi (A) and CaSi (B) caused the release of large levels of $\beta \mathrm{Glu}$, a lysosomal acid hydrolase. $\mathrm{CaSi}$ (C), CaSi (D), and magnetite caused the release of essentially similar levels of $\beta \mathrm{Glu}$. $\mathrm{CaSi}$ (E) also caused the release of significant amounts of $\beta G l u$, this was due in part to the material's cytotoxicity.

\section{Discussion}

The in vitro cytotoxicity of dusts towards macrophages is often used as a predictive test of the potential fibrogenicity of dusts in vivo. Only one of the five calcium silicates had a clear cytotoxic effect towards the cells but since there are no data on long
Table 5 Specific surface area of CaSi

\begin{tabular}{lr}
\hline & $\begin{array}{c}\text { Specific surface area } \\
m^{2} \times g^{-1}\end{array}$ \\
\hline CaSi A & $5 \cdot 1 \pm 0.2$ \\
CaSi B & $5 \cdot 3 \pm 0.2$ \\
CaSi C & $18.6 \pm 0.5$ \\
CaSi D & $50.1 \pm 0.5$ \\
CaSi E & $22.9 \pm 0.5$ \\
\hline
\end{tabular}

term fibrogenicity in vivo, we cannot say whether the test has predictive value for these materials.

In haemolysis studies on the same materials all the calcium silicates were haemolytic with (C), (D), and (E) having greater activity than (A) and (B), thus there was no agreement between the macrophage cytotoxicity data and the haemolysis data.

The reason for the cytotoxity of $\mathrm{CaSi}(\mathrm{E})$ is not clear. It differs from the non-cytotoxic CaSi (D) in having a fibrous morphology. Chamberlain et al showed that the morphology of the mineral Dawsonite was an important factor in its cytotoxicity towards macrophages, the long and thin fibres possessing greater activity. ${ }^{24}$ Thus the toxicity of $\mathrm{CaSi}$ (E) could be related to its morphology. By contrast, $\mathrm{CaSi}$ (A) which presented even longer fibres, was not cytotoxic. In this mineral, however, the total fibre number per unit weight was 20 times less than for $\mathrm{CaSi}(\mathrm{E})$.

The lack of cytotoxicity with $\mathrm{CaSi}(\mathrm{C})$ and $\mathrm{CaSi}$ (D) was surprising since they contained about $10 \%$ quartz as determined by $x$ ray diffraction analysis. The quartz content, however, was much lower when infrared analysis was used. This discrepancy between XRD and IR analysis is probably due to the formation of a calcium silicate layer on partly reacted quartz particles during synthesis of the material. This layer cannot be penetrated by the IRlight. $\mathrm{CuK} \alpha x$ ray radiation, however, will easily penetrate this layer, and the covered particles will contribute to the total $x$ ray signal. Thus the coating on the quartz may have masked its cytotoxic effect in the short term macrophage test. Residence in tissue fluids, however, could possibly result in the removal of this coating and the materials could possibly become biologically active in vivo.

The wollastonites $\mathrm{CaSi}$ (A) and $\mathrm{CaSi}$ (B) caused

Table 4 Chemical formula of main component and quartz content of CaSi

\begin{tabular}{|c|c|c|c|}
\hline Sample & $\begin{array}{l}\text { Chemical formula of } \\
\text { main component }\end{array}$ & $\% \mathrm{SiO}_{2}$ & Presence of fibres \\
\hline $\begin{array}{l}\text { CaSi (A) (US wollastonite) } \\
\mathrm{CaSi}(\mathrm{B}) \text { (natural wollastonite) } \\
\mathrm{CaSi} \text { (C) (synthetic wollastonite) } \\
\mathrm{CaSi} \text { (D) (synthetic tobermorite) } \\
\mathrm{CaSi} \text { (E) (synthetic tobermorite } \\
\text { and xonotlite) }\end{array}$ & $\begin{array}{l}\mathrm{CaSiO}_{3} \\
\mathrm{CaSiO}_{3} \\
\mathrm{CaSiO}_{3} \times 2.5 \mathrm{H}_{2} \mathrm{O} \\
\mathrm{Ca}_{5} \mathrm{Si}_{6} \mathrm{O}_{17} \times 2.5 \mathrm{H}_{2} \mathrm{O} \\
\mathrm{Ca}_{5} \mathrm{Si}_{6} \mathrm{O}_{17} \times 2 . \mathrm{O}_{2} \\
\mathrm{Ca}_{6} \mathrm{Si}_{6} \mathrm{O}_{17}(\mathrm{OH})_{2}\end{array}$ & $\begin{array}{r}-2 \pm 1 \\
9 \pm 1 \\
10 \pm 2 \\
2 \pm 1\end{array}$ & $\begin{array}{l}+ \\
+ \\
- \\
+\end{array}$ \\
\hline
\end{tabular}




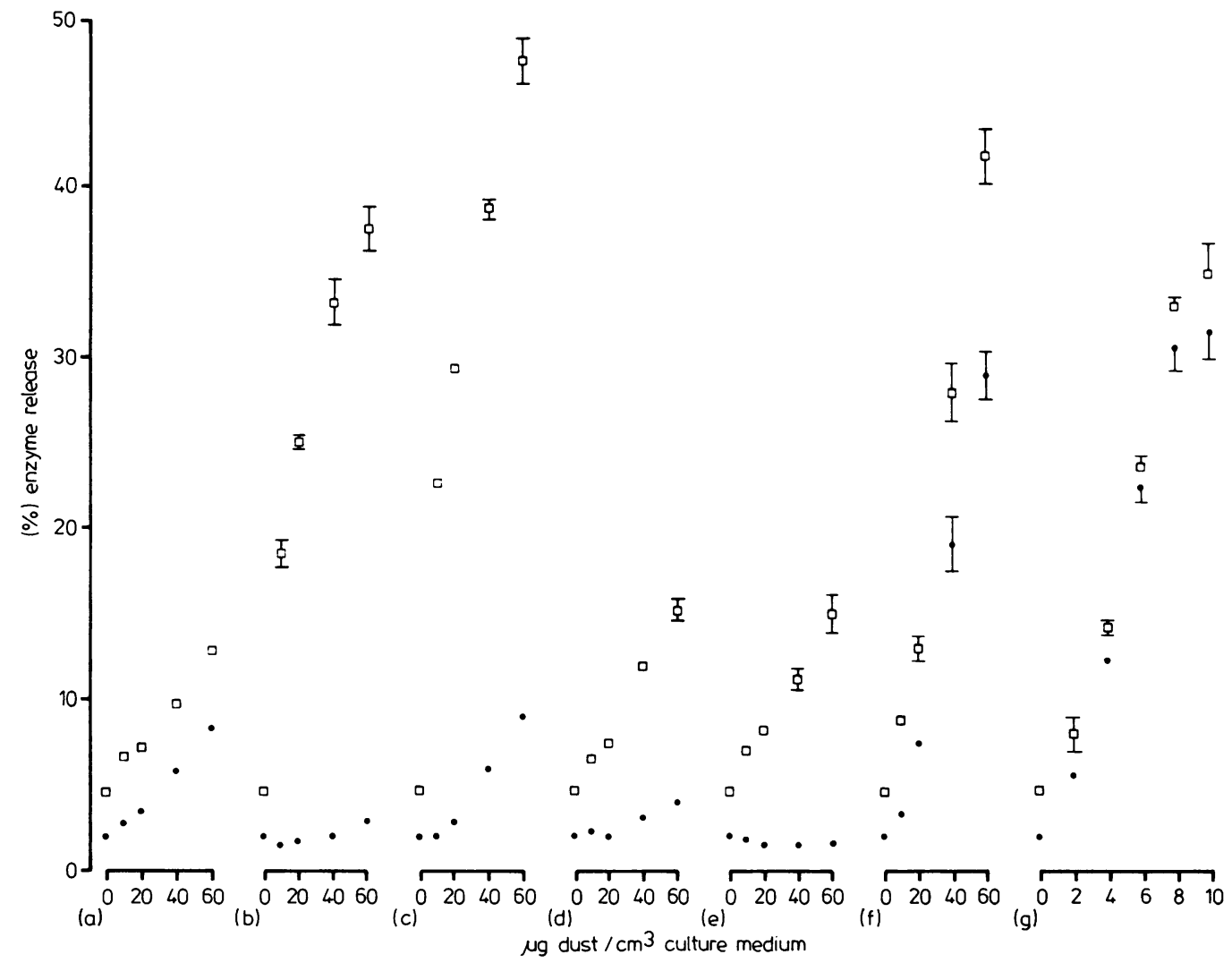

Fig 2 Release of lactate dehydrogenase (LHD) $\bullet$ and $\beta$-glucuronidase ( $\beta G l u) \square$ from macrophages after dust treatment. (a) Magnetite. (b) CaSi (A). (c) CaSi (B). (d) CaSi (C). (e) CaSi (D). (f) CaSi (E). (g) DQ12 quartz.

the release of high levels of $\beta$ Glu from the macrophages without appreciable cell death. This "selective" release of a lysosomal enzyme has been seen with chrysotile and several non-mineral particulates and soluble stimuli of chronic inflammation. ${ }^{25} 26$ We have also found, however, that chalk $\left(\mathrm{CaCO}_{4}\right)$ and gypsum $\left(\mathrm{CaSO}_{4}\right)$ (but not dicalcium phosphate) cause a selective release of $\beta$ Glu. There is no evidence to suggest that these materials cause chronic inflammation and lung fibrosis. Thus the significance of acid hydrolase release from macrophages in vitro so far as the potential pathogenicity of the materials in vivo is concerned is not clear. The mechanism of "selective" enzyme release is not understood, although one possibility is that it is due to the incomplete phagocytosis of long fibres by the macrophages resulting in incomplete formation of the secondary lysosome around the mineral, thus resulting in the leakage of lysosomal enzymes. ${ }^{27-29}$ This mechanism could apply for $\mathrm{CaSi}$ (A) but would be an unlikely explanation for the selective enzyme release caused by $\mathrm{CaSi}$ (B) which contains few fibres.

Nichols recently showed that smooth tubules and coated vesicles import horse radish peroxidase into alveolar macrophages. ${ }^{30}$ As the tubules and vesicles are internalised they fuse with lysosomes, where digestion of the enzyme occurs. Since pinocytosis and digestion are closely coordinated, however, sometimes the outer ends of the tubules remain open to the plasmalemma even though their inner ends have already merged with lysosomes, thus providing a route through which lysosomal enzymes can be released from the cell. The effect, if any, of calcium silicates on pinocytosis, however, has not been studied.

There is no relation between the specific surface area of the minerals and the release of enzymes. Chemical and other physical characteristics are thus more important factors for these biological effects.

Since wollastonite samples contain fibrous particles, their ability to cause pleural sarcoma after 
intra-pleural implantation has been studied. Stanton et al examined four separate samples, only one of which was completely fibrous. ${ }^{31}$ Their ability to cause pleural tumours was low as was their content of long, thin fibres.

Given the wide variation in particle morphology of calcium silicates, great caution should be exercised in comparing the biological effects of different materials when evaluated in different laboratories. The need for standard calcium silicate samples (as developed for asbestos ${ }^{32}$ ) for the assessment of their biological activity seems very important.

We thank Mr J Skidmore for preparing the CaSi (A) sample and Dr J C Wagner for reading and Mrs R Hill for typing the manuscript. The Royal Norwegian Council for Scientific and Industrial Research is acknowledged for financial support of this project.

\section{Requests for reprints to VS.}

\section{References}

' Elevatorski EA. Wollastonite. In: Lefond SJ, ed. Industrial minerals and rocks. New York: American Institute of Mining, Metallurgical and Petroleum Engineers Inc, 1975:1227-33.

${ }^{2}$ Shasby DM, Petersen M, Hodons T, Boehlecke B, Merchant J. Respiratory morbidity of workers exposed to wollastonite through mining and milling. In: Lemen R, Dement FM, eds. Dusts and disease. Park Forest South, Illinois: Pathotox Publishers, Inc, 1979:251-6.

${ }^{3}$ Huuskonen MS, Tossavainen A, Koskinen $\mathrm{H}$, et al. Wollastonite exposure and lung fibrosis. Environ Res 1983;30:291-304.

4 Richards R, Tetley TO, Hunt J. The biological reactivity of calcium silicate composites: in vivo studies. Environ Res 1981; 26:243-57.

${ }^{5}$ Hunt J, Pooley FD, Richards R. Biological reactivity of calcium silicate composites: in vitro studies. Environ Res 1981; 26:51-8.

- Skaug V, Gylseth B. Hemolytic activity of five different calcium silicates. Environ Health Perspect 1983;51:195-203.

${ }^{7}$ Marks J, Nagelschmidt G. Study of the toxicity of dust with use of the in vitro dehydrogenase technique. AMA Archives of Industrial Health 1959;20:383-9.

Styles JA, Wilson J. Comparison between in vitro toxicity of polymer and mineral dusts and their fibrogenicity. Ann Occup Hyg 1973;16:241-50.

'Davies R, Chamberlain M, Brown RC, Griffiths DM. Identification of toxic mineral dusts using mammalian cells. Transactions of the Royal Society of Edinburgh Earth Sciences 1980;71:181-4.

${ }^{10}$ Davies P, Bonney RJ. Secretory products of mononuclear phagocytes: a brief review. J Reticuloendothel Soc 1979 26:37-47.

"Davies P, Allison AC, Ackerman J, Butterfield A, Williams S. Asbestos induces selective release of lysosomal enzymes from mononuclear phagocytes. Nature 1974;251:423-5.
${ }^{12}$ Davies $R$. The effect of dusts on enzyme release from macrophages. In: Brown RC, Chamberlain M, Davies R. Gormley IP, eds. The in vitro effects of mineral dusts. London: Academic Press, 1980:67-74.

${ }^{13}$ Timbrell V, Hyett A, Skidmore JW. A simple dispenser for generating dust clouds from standard reference samples of asbestos. Ann Occup Hyg 1968;11:273-81.

14 Wright BM. A new dust-feed mechanism. Journal of Scientific Instrumentation 1950;27:12-5.

15 Joint Committee of Powder Diffraction Standards Search Manual. In: Berry L, ed. Fink method. Swarthmore: JCPDS, 1974. (Obtainable from JCPDS, 1601 Park Lane, Swarthmore, Pennsylvania 1908.)

16 Joint Committee of Powder Diffraction Standards. In: Berry L, ed. Selected powder diffraction data for minerals. Swarthmore: JCPDS, 1974.

${ }^{17}$ Bye E, Edholm G, Gylseth B, Nicholson DG. On the determination of crystalline silica in the presence of amorphous silica. Ann Occup Hyg 1980;23:329-34.

${ }^{18}$ Dodgson J, Whittaker $W$. The determination of quartz in respirable dust samples by infrared spectrophotometry-1. The potassium bromide disc method. Ann Occup Hyg 1973; 16:373-87.

19 Gordon S, Werb Z, Cohn ZA. In: Bloom BR, David JR, eds. In vitro methods in cell mediated and tumour immunity. London: Academic Press, 1976:344.

${ }^{20}$ Morgan DML, Vint S, Rideout JM. Continuous flow fluorimetric assay of lysosomal enzymes. Med Lab Sci 1978;35:335-41.

${ }^{21}$ Robock K. Standard quartz DQ12 $<5 \mu \mathrm{m}$ for experimental pneumoconiosis research projects in the Federal Republic of Germany. Ann Occup Hyg 1973;16:63-6.

${ }^{22}$ Davis JMG. The fibrogenic effect of mineral dusts injected into the pleural cavity of mice. BrJ Exp Pathol 1972;53:190-201.

${ }^{23}$ Braunauer S, Emmet HP, Teller NE. Adsorption of gases in multimolecular layers. Journal of the American Chemical Society 1938;60:309-19.

${ }^{24}$ Chamberlain M, Brown RC, Davies R, Griffiths DM. In vitro prediction of the pathogenicity of mineral dusts. Br J Exp Pathol 1979;60:320-7.

${ }^{25}$ Schorlemmer HU, Ferluga J, Allison AC. Induction of lysosomal enzyme release from cultured macrophages by dextran sulfate. Clin Immunol Immunopathol 1977;7:88-96.

${ }^{26}$ Schorlemmer HU, Ferluga J, Allison AC. Interactions of macrophages and complement compounds in the pathogenesis of chronic inflammation. In: Willoughby DA, Giroud JP, Velo GP, eds. Perspectives in inflammation. Lancaster: MTP Press Ltd, 1977:191-209.

${ }^{27}$ Bruch J. Response of cell cultures to asbestos fibres. Environmental Health Proceedings 1974;9:253-4.

${ }^{28}$ Ackerman NR, Beebe JR. Release of lysosomal enzymes by alveolar mononuclear cells. Nature 1974;247:475-7.

29 Johnson NF, Davies R. The effect of crocidolite and chrysotile on peritoneal macrophages: a study by transmission and scanning electron microscopy. In: Brown RC, Chamberlain M, Davies $R$, Gormley IP, eds. The in vitro effects of mineral dusts. London: Academic Press, 1980:97-103.

${ }^{30}$ Nichols BA. Uptake and digestion of horse radish peroxidase in rabbit alveolar macrophages. Lab Invest 1982;47:235-46.

${ }^{31}$ Stanton MF, Layard M, Tegeris A, et al. Relation of particle dimension to carcinogenicity in amphibole asbestoses and other fibrous minerals. Journal of the National Cancer Institute 1981;67:965-75.

${ }^{32}$ Timbrell V, Rendall REG. Preparation of the UICC standard reference samples of asbestos. Powder Technology 1971; 5:279-87. 